\title{
2. Connections of Spirit: Kuninjku Attachments to Country
}

\author{
Luke Taylor
}

This place, the creek and water, we love this country, we Aboriginal people. We love it. The old people were the same, attached to the water and this land. The old people, our grandfathers and grandmother's, great grandparents, our ancestors, they lived here in this place, put here for them. That's how we talk about our land.

Our spirits lie in the water...

When we camp by the creek it soothes our spirits and keeps us cool. We understand it at places where my father took us, and my grandfather, mother's mother and father's mother. Today we want to continue to teach each other these things so we can understand. We did not invent this ourselves. The first ancestors from long ago are the origin. (Namirrkki, 2004: 112)

This is the way Ivan Namirrkki, born in 1961 and a Kuninjku language speaker from western Arnhem Land, describes his attachment to his country and its waters. Namirrkki is musing on his relationship to a camping place called Wakyoy on Manggabor Creek, a tributary of the Liverpool River, that is a short walk from his outstation at Kumurrulu. In a couple of sentences he has outlined an attachment which speaks to his understanding of creation and the intrinsic bodily link between himself and the place where he is living. The country was 'put there' by the Ancestral beings for Namirrkki's family and his continued maintenance of this country venerates these beings and the succession of human ancestors who have also lived there. There is a power in country that radiates to all those who live there and becomes incorporate in humans by virtue of their spiritual makeup. In this chapter I want to trace Kuninjku thinking about their connection to country to explicate Ivan's statement above. In doing so I wish to reveal the local conception of country that Kuninjku focus upon as important to their contemporary existence.

Kuninjku cast this relationship as a spiritual one, as a direct connection with Ancestral creator beings, and this religious outlook shapes the beliefs and values which are the framework for interpreting the meaning of their actions in the world (Taylor, 1996). I wish to focus on one man's understanding of his interrelations with the Ancestral powers, landscape features, and species of his country as an example of the broader Kuninjku perspective. In examining these 
connections we find explanations for Namirrkki's motivation to remain living on his country, particularly the importance of establishing the outstation at Kumurrulu. One context for this analysis is a recurring debate about the most appropriate mode of development for Aboriginal and Torres Strait Islander peoples living in remote regions.

The Kuninjku are traditional owners of lands to the south-west of the town of Maningrida in Arnhem Land in the Northern Territory (Altman, 1987; Taylor, 1996). All of Arnhem Land is formally owned by Aboriginal people as a result of the Aboriginal Lands Rights Act Northern Territory 1976 (Cth). Today many Kuninjku families live on outstations or homeland centres on their own lands and regularly commute to Maningrida for services and supplies. Occasionally families will reside in the larger town in the wet season when transport to outstations may be difficult or for social reasons such as avoidance after a death or to ensure regular health care for a new born.

For some outsiders, these homelands appear to be an anachronism. For example Hughes (2007) points to the lack of development opportunities at such locales and criticises the effectiveness of the decentralised delivery of schooling and health services entailed by such living arrangements. The former Federal Minister for Aboriginal Affairs described these locations as 'cultural museums' (Vanstone, 2005). The current Northern Territory government policy does not support the funding of new outstations and otherwise promotes a reduction in government support of outstation infrastructure while favouring the support of 'growth towns' (Northern Territory Government, 2009). There is a belief that the government can create stronger employment opportunities in the towns and argument as to whether Aboriginal families should be compelled to move to larger settlements in order that services become more effective. Such measures that impact upon where Aboriginal people live can be considered a subset of a much broader program of intervention and enforced behavioural change associated with the Northern Territory Emergency Response implemented in June 2007.

The circumstances of outstation life vary across the continent and the example I describe here may not be typical. In respect to Kuninjku I argue that these more remote communities are not anachronisms so much as modern and culturally appropriate adaptations to the changed circumstances of their life. Other authors (such as Merlan, 1998, 2005 and Hinkson and Smith, 2005) have explicated how it is appropriate to consider the profoundly intercultural aspects of contemporary Aboriginal life. New expressions of Aboriginality are produced through intercultural experiences and, in the Kuninjku case, homelands are an expression of an extremely resilient religious outlook which venerates Ancestral presence in the land as well as considerations of the multiple servicing benefits that derive from the creation of relatively permanent 
small settlements in close proximity to a town. As Povinelli (1993) and Altman (1987) have shown, Aboriginal ideas regarding the importance of maintaining a presence on the land and of 'working' it - through the performance of ceremony, maintenance of sites, establishment of outstations, and continued hunting and gathering activities - continue to be central in the changed and intercultural circumstances of Aboriginal lifeworlds in the Northern Territory. It is important to acknowledge that Kuninjku developed a strong experience of town life at Maningrida in the 1960s but that they rejected this form of permanent settlement and the overt assimilation programs that they experienced there. Rather, many Kuninjku prefer to live on their country but regularly commute to the town as they need to - they make use of the services of the town on their own terms. Authors such as Tatz (1964), Rowse (1998), Altman (1987) and Folds (2001) have highlighted the way that assimilationist policy proscriptions have a history of failure in the Northern Territory partly because they did not account for the continuing strength of Aboriginal sociality and in particular the connections with country. Altman (2007a, 2007b) has pointed to the way that current government development agendas regarding Aboriginal employment, enterprise development, education, housing, health, and service delivery more broadly have a strongly coercive aspect. He notes that these policies do not engage with Aboriginal views regarding development that is appropriate for their families and on their lands. One of the points I wish to develop in this paper is the depth of Kuninjku concern to remain on their lands. Altman reveals that another weak point of current policies is the lack of appreciation of structural impediments to Aboriginal engagement with mainstream economic opportunity in some locales. Many communities are simply too far removed from markets and marketable resources.

Outstations comprise a relatively new and sedentary form of settlement as opposed to pre-contact forms of mobility across vast areas of land (Parliament of the Commonwealth of Australia, 1987). Kuninjku country is now crosscut with the new infrastructure of roads, airstrips, telecommunications, solar electricity, bores to provide water supplies, and buildings used to deliver health and education services. In the siting of homelands, Kuninjku such as Ivan Namirrkki have negotiated the need to sustain connections with particular country as well as take advantage of new opportunities provided by new technologies. Altman and Hinkson (2007a) have made the point that new technologies, such as the motor vehicle, have already profoundly transformed Kuninjku lives and allow for new expressions of identity. Kuninjku modernity is geographically more expansive than precontact forms when we consider the frequency of travel from outstations to the services and sociality offered at Maningrida. Similarly the art market has facilitated some Kuninjku to engage with audiences on a world stage (Altman and Hinkson, 2007a: 198-199). Kuninjku continue to be engaged in processes of social change but they do this in a way that involves assertions 
of a unique religious outlook and associated core values as bininj or Kuninjku people even as they engage with balanda, or non-Aboriginal people. Chief among their developing political concerns is the need for balanda to respect their attachments to country.

\section{Namirrkki's outstation at Kumurrulu}

Namirrkki lives at an outstation called Kumurrulu on elevated land amid a stringybark forest overlooking the valley of Manggabor Creek. This locale is on the edge of the Arnhem Land escarpment where the stone country meets the floodplain of the Liverpool River. In comparison with many other Australian landscapes this region is tremendously fertile in terms of the variety of foods that may be hunted and collected and Namirrkki's family exploits multiple ecological zones in the near vicinity. The floodplains in particular are breeding grounds for many species of waterbirds and saltwater and freshwater fish abound in the rivers. Bush foods are supplemented by store foods including staples such as flour and bread, tea, sugar and tinned foods purchased in Maningrida during regular visits or delivered by plane or boat during the wet season.

A short ten minute drive brings the family to the favourite hunting camp of Komnudd near Marrkolidjban outstation at the confluence of the freshwater and saltwater sections of Muralidbar Creek, a tributary of the Liverpool River. There is good shade at this place as well as the mounded remains of cooking fires that go back for many generations. There was a hollow log coffin placed in the trees here so that the spirits of these dead people could look out over the country that made them 'happy'. Substantial seasonal catches of barramundi are made here and there is an important site for the Barramundi Dreaming in this region. Other saltwater and freshwater fish species congregate in this locale. The camp is also adjacent to the major floodplain of the Liverpool River. This vast expanse is inundated in the wet season. When the waters recede Namirrkki's family can spear barramundi trapped in the shallow waters or, by stalking through the reeds with shotguns, may hunt the many species of bird life including magpie geese, whistle duck, brolga, and ibis. As the floodplain dries off more extensively, and Namirrkki's family burn the remaining reeds, large numbers of freshwater turtle may be dug from the drying mud by observing their breathing holes and probing with iron rods. Feral water buffalo and pig often travel down the river valley and range out across the floodplain and these introduced species are also tracked and shot to provide major supplies of fresh meat that are shared among multiple families.

As the dry season progresses, Namirrkki's family also camp for short periods on the white sand beaches of Manggabor Creek. Trees along the bank provide deep 
shade and Namirrkki's family camp out with mosquito nets strung from stakes driven into the sand. At this time Namirrkki will gradually burn off different areas as the spear grass dries out. He may also pay host to visiting families who come to fish for different species during the day. As the creek transforms into a series of separate billabongs people can fish with lines for barramundi, saratoga, catfish or smaller freshwater species. Occasionally saltwater crocodiles are speared for food in these billabongs. As the waters become more shallow, mud mussels, file snake and yabbies can be collected.

Also at this time, a short journey by four wheel drive accesses the tidal reaches of the Liverpool River. Here people can fish for large fish species such as shark, stingray, barramundi and catfish. Mangrove forests adjacent to the river hold colonies of flying fox which are hunted with shotguns. Wallabies are often hunted where they are sheltered in cooler jungle areas adjacent to the river.

In the wet season all these areas become inundated with dangerous floodwaters and transport becomes much more limited. However during this time the rock country and forest areas that surround Kumurrulu remain accessible and it is also the time when many fruiting tree species such as green plum, red apple and white apple can be harvested. Kangaroo and emu can be hunted in the rock country, and buffalo and pigs in the billabongs and springs of the higher reaches of the freshwater streams. Kumurrulu has access to an airstrip near Marrkolidjban outstation and boat landing on the Liverpool River for the purchase of supplies if the family chooses to stay in residence at this time. However, if Namirrkki does not have a working vehicle, or if his family miss the sociality of the town, he may relocate to stay with relatives in Maningrida during the height of the wet season.

Namirrkki uses Kumurrulu outstation as a relatively permanent base from which he can exploit a variety of ecological zones that include the rock country, savannah woodlands, freshwater streams, saltwater rivers, patches of jungle, mangroves, and floodplains. Hunting and collecting can involve short day trips from the outstation on foot or by car or short term relocation to camps situated closer to these resources. Altman (1984: 36; 1987) identifies a similar set of land systems and patterns of land use by people living at nearby Mumeka outstation. Access to food resources is an extremely important pragmatic reason for occupying this locale and this pattern of use of the land is emulated by many other Kuninjku families in approximately 15 other Kuninjku outstations (Altman, 1987, 2003). Hunting and gathering remains a central form of working Kuninjku country. Elsewhere in the top end of the Northern Territory, Povinelli (1993) has also made the point that such activity establishes and reiterates the links between people and country and that hunting and gathering is continuous with more religious connections to country. Povinelli documents the creation of connections between contemporary humans and Ancestral presence inside the 
earth by means of the 'sweat' of human toil that can be sensed by Ancestral spirits and through the use of language that is appropriate to communicate to the spirits of country.

\section{Country of the spirit}

Namirrkki has spoken of his love for country particularly the soothing qualities of living adjacent to its important waters. There is also a confidence and peace derived from living in one's heartland that flows to all activities conducted there. An understanding of the importance of country provides the context for more developed understanding of Kuninjku concepts of personhood, sociality, power, and health, as well as local constructions of other frameworks of human experience such as aesthetic experience.

Namirrkki says that one of the important reasons that he lives at Kumurrulu is because it allows him to protect the important site for the Leech Dreaming at Yibalaydjyigod and for the Maggot Dreaming at Yirolk. Kuninjku call such sites djang and say that they were created by the Ancestral beings also called djang. The use of this same term reveals the identity between country and Ancestral species that is at the core of Kuninjku thinking about country and ecological relationships. For Kuninjku the Ancestral beings are the source of original animating life force or kun-ngudj and this power may be sourced at djang sites. For example, I have briefly mentioned the relationship between the Barramundi djang and the prolific catches of barramundi in the Marrkolidjban area. At this locale in the past increase ceremonies were performed where ochres from the djang site were cast into the waters in order to release the fertilising powers of the Ancestral Barramundi.

In Namirrkki's eyes Leech and Maggot are major djang. Leech relates to a particular spring in the swampy section of Manggabor Creek. The Maggot djang at Yirolk is a waterhole that features a rock emerging from the water and surrounded by waterlilies. It is said that all the spirits of deceased landowners are inside a cave in the rock where it is covered by water. Kuninjku say that young people can't touch the water or the waterlilies and yet old and powerful people can drink at this place. Damaging the site would release an uncontrolled pestilence of these species into the world and anger the Rainbow Serpent, Ngalyod, that protects the site. Namirrkki says there is a tunnel made by the Maggot djang under the ground to another site on Bat Island near Maningrida in Myeri clan lands. In this respect the journey of the Ancestral being is considered to link Namirrkki to a wider polity of clans in the region. Namirrkki dances with the owners of this site in recognition of their joint relationship to a species that travelled through both their countries. Namirrkki occasionally paints this subject with 
lattices in the painting that show connections between different waterholes in the forms of the tunnels or creeks that link the different sites. Thus alliances between regional groups are also articulated on the basis of shared concern for this species. Keen (1994) has elaborated on this point in respect to Yolngu groups in north-east Arnhem Land; the presence of similar ecological zones and species in the countries of different clan groups can be used as the basis for alliances of shared responsibility in respect to particular sets of Ancestral beings. Keen (1994: 123-124) elaborates that the heterogeneity of ecologies within a clan's land provides the basis for relations with multiple other clans in the region of the same patrimoiety and links to the multiple ceremonies celebrating the different beings of that moiety.

Leech feeds on the blood of living animals and humans and has a body form like a small snake. Maggot is involved in processes of bodily decay through eating away the flesh of the dead and is also snake-like in its bodily form. In the Ancestral period, these beings are said to have been much larger and very dangerous. However these beings are also considered to be potentially dangerous and harmful to humans in the present if they were to multiply uncontrollably through damage to the site. In their fondness for eating flesh, their snake-like form, and their association with death and decay these species are linked to the conception of the Rainbow Serpent. As Morphy (2008) has shown for the Yolngu Mangalili clan in eastern Arnhem Land, themes associating Maggot with death and decay are also linked with purification and rebirth in the context of mortuary ceremonies. In Kuninjku thinking these sacred sites are also considered to be sources of fertilising power and, through the agency of Ngalyod, are linked to ideas regarding the recycling of human souls.

Kuninjku consider that the powers that djang invest in the land also animate all humans. In particular Kuninjku gain their kunmalng or sacred soul from these sites. Such spirits living in the deep waters at djang locales can make women conceive and, upon death, the spirits are said to return to these places. People also gain their personal names from places in their country and often also from their father's father thus highlighting the theme of patrilineal inheritance of these places (Evans, 2003: 68). One way of talking about powerful sites in the country is to use the term kubolk murrng-rayek, meaning literally 'country of strong bones'. Old men also have a measure of this power and can be described as developing 'strong bones' in the same way. In these respects the country, Ancestral species, and contemporary humans can be considered to be spiritually continuous (see Taylor, 1996). Namirrkki's desire to live near these sites is primarily an expression of his responsibility to tend to the Ancestral powers of the site and to protect the souls of deceased people of previous generations, and the, as yet, unborn souls of new people. For Namirrkki, living near these powerful sites gives him spiritual strength. He uses the language of 'strong bones' to describe the way his knowledge of country gives him power. 
Kuninjku speak to the spirits of country and say that the spirits speak back. Visitors who do not know the site are introduced to it by the landowner who rubs them with his sweat and calls to the relevant spirits. Being rubbed with sweat ensures the spirits do not smell out the strangers. In addressing the spirit world, land owners must use the correct language and employ a special linguistic register called kundangwok which is clan specific (Garde, 2004: 110111). Visitors must be identified by their place in the local kinship system and landowners plead with the spirits not to harm them. Strangers who wander unsupervised across country and do not understand its protocols can cause considerable anxiety among landowners and may inadvertently anger the spirits. For example, Ivan Namirrkki's father Peter Marralwanga acted to protect the Yirolk site in 1973 when he erected a barricade of tin drums across the road to protect his country after damage to the site by an ignorant road grading party (Cooke, 1981). It is also common during hunting exploits to hear land owners pleading with the spirits to help them to find game.

Waterholes such as Yirolk are often large and still bodies of water. The creation stories relating to such sites often involve the original Ancestral species angering the Rainbow Serpent Ngalyod in some way so that Ngalyod rises from inside the earth swallows the other being and draws them back down and this act effects the creation of the site. Ngalyod is seen as the original and most powerful being and all subsequent Ancestral beings came out of her body. The conceptualisation of Ngalyod, often described as the earth 'mother', involves a consideration of a ubiquitous life force existing inside the earth (Taylor, 1990). All sites and Ancestral species in the region are linked on the basis that, hidden inside the earth and in deep waters, Ngalyod is tending to them all.

Kuninjku say that in the wet season Ngalyod rises from these waters into the sky to make the monsoon rains. The rainbow seen in the rain is considered to be a manifestation of Ngalyod's spirit and the huge energies of the wet season storms are expressions of Ngalyod's power. The rain brought by Ngalyod rejuvenates the earth, makes the grass grow high, the sap run in the trees, and animals such as the birds and fish of the floodplains repopulate the world. The well being of Kuninjku is explicitly linked with this cycle as they hunt for game after the storms. The water cycle is intrinsic to Kuninjku thinking about Ngalyod. Ngalyod reaches from the earth and into the sky to vomit the wet season rains. These rains flood low lying areas and the waters gradually run away to the sea and to the permanent water sources that are djang as Ngalyod swallows these waters in the dry season. Kuninjku say that Ngalyod creates links between these waterholes by tunnelling under the ground and they indicate that Ngalyod can be responsible for creating springs that bubble with fresh water at some distance from flowing creeks. Water is perceived as a conduit of Ancestral power and a common way this is articulated is through the belief that the spirits of unborn humans live at djang sites as small fish with a rainbow sheen. 
One purpose of the recreation of Ancestral events in major regional ceremonies such as Kunabibi and Yabbadurruwa, is to ensure the arrival of the wet season and thus the release of the powers of djang through the agency of $\mathrm{Ngalyod}$. Many participants from the multiple clans of the region gather for these ceremonies and the performance is said to ensure the good health of the participants and maintain the link between the multiplication of species and continued opportunities for good hunting. Specifically participants say that the ceremony makes them feels strong, healthy and 'fat'. The term 'fat' also has many other reverberations with health and vitality in the natural world; the ceremony makes the 'fat' or sap run in the trees and causes animals to put on the fat that is so highly valued. Elsewhere, McDonald (2003) has shown there are clear health benefits from eating the fat of bush animals as opposed to shop purchased meat. Other researchers have measured a correlation between outstation residence and improved health outcomes in this locale (Burgess et al., 2005) thus lending objective support to Kuninjku perceptions of the link between living on country and achieving better health.

\section{Following the ancestors}

While Kumurrulu is a relatively new outstation established just a few kilometres from the larger Marrkolidjban outstation, Namirrkki's family have a long history of living in this area. Namirrkki explains that it was in discussion with his father Peter Marralwanga before his death in 1987 that they together decided that Kumurrulu would be a good location for a new outstation.

Marralwanga has described that he was born here and that he moved to live in different camp sites across the region throughout his life (see, Taylor, 1996: 65-69). Other Kuninjku say that Marralwanga received promised wives from families who lived in the Marrkolidjban region and that in recognition of a lifetime of association he became the acknowledged ceremonial leader and 'boss' for the locale. Government patrol officer Gordon Sweeney found many families living in this district during a patrol in 1939 (Sweeney, 1939). Another officer Syd Kyle-Little (1957: 215-216) reports many people living at Marrkolidjban in 1949 and Peter Marralwanga remembered him from this time. Patrol officer Ted Evans (1963) led an expedition to establish the Maningrida/Oenpelli road and found Kuninjku families camped nearby at the Liverpool River crossing in 1963. It is important to acknowledge that Marralwanga's own Kardbam patri-clan territory is further to the south-east. However Kuninjku explain that movement beyond one's own country was a characteristic of pre-settlement life as were negotiations to gain residence and ceremonial rights in new lands. Hiatt (1965: 18-20) reports similar patterns among the neighbouring Gidjingali. 
Maningrida was established as a government settlement in 1957. However Peter Marralwanga was not generally interested in the attractions of permanent living in the town. This kind of existence was foisted upon his family in the 1960 s as a feature of the development of Maningrida as a government run showcase of the effectiveness of assimilation policies. Kettle (1967: 206) notes that Marralwanga was eventually encouraged to move to live at Maningrida in 1963 to seek medical assistance for Namirrkki's elder brother who was then very young and showing early signs of leprosy. At Maningrida Kuninjku were required to eat in communal dining rooms and were trained to work in forestry, agriculture and fishing enterprises. Substantial infrastructure was established in the town to support these industries. Today Maningrida is surrounded by a grid of dirt tracks built to service tracts of cypress pine conserved for the forestry enterprise. An abandoned fire tower stands at the entrance to the town although, ironically, the forestry workers could never hope to control the multiple fires that swept through the stands of timber. Fires have been lit to manage lands in this region for millennia. Haynes (1978) documents the growing resentment of landowners to the expanding forestry activities at Maningrida and in particular a turning point in relations caused by damage to an important sacred site in 1971 by forestry workers bulldozing a road. While the Aboriginal men were encouraged to work in these enterprises, the women were trained as domestic servants and cleaned the homes of the white staff during the day. Haynes (1978) notes the anger about so many balanda working in the town and growing calls for removal of the forestry from the late 1960s and for Aboriginal self management at Maningrida in the early 1970s.

Over time the enterprises in the town gradually collapsed partly because of distance from markets, transport difficulties, and lack of motivation among Aboriginal people for the highly controlled lifestyle (Altman, 1987: 4-5, 1819; Taylor, 1996: 36-37). In order to develop Maningrida some 13 different language groups from the north central Arnhem Land region were forced to live in close proximity and violent disputes were common. Peter Marralwanga, for example, carried the scar of spear wound in his chest received in 1964 during a major confrontation. He is reputed to have killed the other protagonist in this exchange.

In the early 1970s the changed policy of self-determination brought in by the Whitlam Government and the hearings of the Woodward Commission into land rights saw a dismantling of this form of enterprise development at Maningrida and encouragement for the different groups to return to their lands. Kuninjku were quick to return and establish outstations in their own lands. With logistical assistance from balanda staff including John Hunter the superintendent at Maningrida, Marralwanga became one of the senior founders of an early outstation at Marrkolidjban in 1973. Marrkolidjban outstation grew over the 
years and came to comprise a substantial assembly of buildings housing multiple family groups. Marralwanga had six wives in total in his life and numerous children. Marralwanga, Namirrkki, and other residents developed a reputation for the production of excellent bark paintings and women produced excellent basketry (Taylor, 1996). Marralwanga enforced a ban on the consumption of alcohol in the outstation to improve its social conditions and to check the visits by countrymen who occasionally brought alcohol from Oenpelli to Maningrida and passed close to the outstation.

While many families still choose to live in the town, Maningrida today is a service centre for some 800 people who live in a total of 32 outstations in an area of 10,000 square kilometres. Kuninjku homelands consist of mudbrick houses, provision for communal facilities such as an outstation school or women's centre, toilets and showers, an airstrip, road access and occasionally a local boat landing, a solar power water bore, and solar powered telephone. As Altman and Hinkson (2007a) report, the tension between permanently sited infrastructure and the need to access country is partly negotiated through the hyper-mobility afforded by motor transport. Kuninjku motor vehicles are rarely idle. Outstation facilities are maintained through the Bawinanga Aboriginal Corporation established in Maningrida to service outstation residents. Schooling is provided through a specifically designed outstation school program attached to the Maningrida School. Balanda teachers visit the outstations for a number of days each week and work with residents of the outstation employed as teacher aids. As detailed above, there is a tension involved in maintaining this new and relatively permanent infrastructure and the desire of most outstation residents to establish less permanent camps in order to exploit seasonal food abundances, visit relatively remote djang sites, or to engage in social activities such as the performance of ceremonies. However service deliverers based in Maningrida have developed a measure of expertise around Kuninjku mobility and, through good communications, can generally manage to accommodate this shifting pattern of residence. The Bawinanga Aboriginal Corporation has used the Australian Government funded Community Development Employment Program in a manner that recognised the work involved in tending to country, managing outstations, developing infrastructure such as housing and roads, as well as for the development of community enterprises such as Maningrida Arts and Culture, a shop and mechanical workshop for outstation residents. However the federal government has moved to change the Community Development Employment Program from its use for part time employment support in remote Indigenous communities to a scheme to ready participants to find full time work outside of the scheme. Former Community Development Employment Program participants will now complete work training activities and receive income support payments until they can find full time employment. Government has 
funded service delivery positions and some ranger positions to assist in the creation of full time work but the number is by no means commensurate with the need in Maningrida.

With the death of his father, Ivan Namirrkki established his outstation at Kumurrulu adjacent to Marrkolidjban. At present the infrastructure at Kumurrulu consists of only one house for Namirrkki and his sons as well as bore and telephone. Namirrkki exhibits strong emotion when he describes how his father guided him to make an outstation near this place. Kumurrulu is an offshoot of the larger Marrkolidjban outstation a few kilometres down the road and now occupied by his elder brother Bill Birriyabirriya. Kumurrulu is one of a second wave of outstations developed as the outstations established in the 1970s become too large. Larger outstations can develop social tensions and fission of large communities is a characteristic way that Kuninjku address such problems. The smaller outstation provides peace and quiet for Namirrkki's family away from Marrkolidjban and yet it is only a short drive to the school located there.

It is important to acknowledge that Namirrkki's outstation is situated in Barbinj clan land although his own Kardban clan country is further south near Mankorlod. Like his father before him he is a recognised boss of these new lands. Kuninjku still strongly recognise the mosaic of patrilineal clan land ownership in western Arnhem Land although they also acknowledge that historical circumstance has seen considerable movement of individuals outside of their own clan territories. Namirrkki's rights in this country have been negotiated over time primarily through his continued residence and intimate knowledge of this locale. This does not mean that the clan associations of country have been blurred, rather they are acknowledged in the present as are the personal historical circumstances that have led to Namirrkki's intimate knowledge of this country. In many respects Namirrkki benefits from the powerful status of his father although it is also true the Namirrkki himself has been politically active in his own lifetime in tending to these lands. Caring for important ceremonial sites is a key activity in this context and for Kuninjku this constitutes extremely valuable work. Namirrkki's status is respected by the jural public of other landowners who jointly maintain Kuninjku ceremonial life. There is a major site for performance of the Kunabibi ceremony near Marrkolidjban and Namirrkki is now broadly recognised as a major djungkay or ceremonial manager for performances of the ceremony at this place. Namirrkki was recently one of the senior hosts for a visit by hundreds of people from the broad region for a performance of this ceremony near his home in 2007. 


\section{Country based enterprises}

My concern has been to explicate some components of the way that contemporary Kuninjku interact with their country and their interpretations of this coexistence. The fundamental bedrock of this connection is Kuninjku belief about the enduring Ancestral energies in their country and their manifestation as life force and human 'spirit'. The important point is that this religious perspective is still central to contemporary Kuninjku life choices. Adaptations to new forms of settlement of their land, new kinds of work effort, and development of new economic opportunities all articulate a concern to nurture this life force at the same time as articulating connections with western or balanda modes of action and thinking. As Merlan (2005) has shown, Aboriginal discourses can serve to reconstruct Aboriginal identity as distinct from western identity in contemporary intercultural contexts. Kuninjku articulate an understanding of their distinctiveness even as they actively engage with these new opportunities.

Kuninjku have readily engaged in new forms of enterprise development suited to their relative remoteness from markets. The production of art and craft was facilitated from the earliest days of settlement of Maningrida and was particularly encouraged to support outstations (Altman, 2004; Taylor, 1996). Recently Kuninjku living at outstations have engaged with more formalised ecological management and cultural tourism programs. Altman (2003, 2005, 2007a) has outlined how Kuninjku can meld an extremely strong desire to maintain an economy of food gathering with income support provided by governments and opportunities to work in market based enterprises to develop what he calls a 'hybrid' economy at Kuninjku outstations. Elements of this concept have been incorporated in the Australian Conservation Foundation's promotion of the 'culture and conservation economy' for Aboriginal communities in northern Australia (Hill et al., 2008: 4-5, 19-21). These characterisations recognise the increasing preference, in some remote Aboriginal lands, for the development of sustainable country based enterprise.

\section{Art market}

Just as the development of outstations can be seen as the negotiation of a new form of expression of Kuninjku identity, Kuninjku participation in the world art market is valued by Kuninjku because it allows for 'new' expressions of identity on a global platform. The market for bark paintings is a very important way of earning an income and an opportunity to teach balanda about Kuninjku culture. Painting is a key means of communicating knowledge about the spiritual power of Kuninjku lands both among Kuninjku and to broader world audiences (Taylor, 1996, 2008). 
Namirrkki often collects bark for painting from the large stands of Eucalyptus tetradonta or stringybark that surround his outstation. Red and yellow ochres can be collected from river and creek crossings. Sacred ochres can also be collected at particular locales along Marrkolidjban Creek. Namirrkki says that his spirit and culture is in the ground at djang sites and when he paints he brings it 'out', brings it forth for all to see (Namirrkki, 2004: 112). Namirrkki was taught many of the stories about his lands from his father as a feature of learning to paint. Often Marralwanga and Namirrkki used to work jointly on a single painting in order that the skills and knowledge could be transferred as part of the younger artist's apprenticeship. On one occasion in 1983 Namirrkki travelled with his father to Perth to attend an exhibition of joint work and this stimulated him to take on a stronger role as a professional artist. Later in his life Namirrkki travelled more broadly in Australia for both group and individual exhibitions (see, Perkins, 2004: 220). Namirrkki can participate in the world art market through the support provided by Maningrida Arts and Culture, a Bawinanga Aboriginal Corporation enterprise, based in the town. Importantly his inspiration comes from sacred places very close to his home including the sites for Leech and Maggot described above. He also paints important djang such as Goanna, Ngalyod and the Nakorrkko creator beings from the lands of his Kardbam patri-clan. There is a strong sense of wellbeing derived from this repeated engagement with imagery of his country and a sense of spiritual connection with previous generations of Kuninjku, particularly his father, also linked with these lands.

Kuninjku aesthetics is grounded in religious conviction. The dazzling designs of Kuninjku paintings evoke the powers that radiate from djang sites. A common subject painted by Peter Marralwanga and Namirrkki was Ngalyod the Rainbow Serpent. The figure was often shown as a great twisting snake that surged with life force. Dazzling designs on the figure's body were suggestive of its rainbow manifestation. The point of painting such work for the market is to expose viewers directly to the power of the Ancestral realm. Following a similar line of argument to that of Deger (2006) in relation to Yolngu use of new film media and Tamisari (2005) in relation to Yolngu dance performance, I argue (Taylor, 2008) that Kuninjku engage with the new opportunities afforded by the art market in order that the aesthetic force of their paintings 'opens' balanda viewers to a new way of seeing the world which has Ancestral presence at its centre.

Feelings for country also inspire innovations in the market context. The style of painting from this region has undergone a major transformation in the last 20 years (Taylor, 2008). Kuninjku artists have moved away from depicting figurative subjects to depicting key sacred waterholes in a more geometric ceremonial style called Mardayin. This style of painting relates to ceremonial body paintings of the same name. Namirrkki for example paints the sites Leech and Maggot and 
other nearby sites in this geometric format (Perkins, 2004: 86). Kuninjku have perceived a greater importance of revealing their ceremonial knowledge about country in this new format and there has been a positive response by the market for these more important paintings. Kuninjku seem more self-conscious about land as spiritual heartland needing to be protected and painting is perceived in a more political sense as one way of continually reasserting the importance of country and its attached values on a world stage.

\section{Ecological services}

Namirrkki's knowledge of the land also provides other economic advantages for his family. Namirrkki and his son Obed work in the Djelk Rangers established by the Bawinanga Aboriginal Corporation and based in Maningrida. The ranger program was established in 1991 as a feature of the Community Development Employment Project and is maintained now through the Working on Country and the Community Development Employment Project and partnerships with multiple other state and federal agencies. Intimate knowledge of country allows participants to engage in land management activities such as feral animal and weed control, species survey and monitoring programs, controlled burning, detection of incursions by foreign fishing vessels and participation in new enterprises such as the breeding and sale of crocodile and long necked turtle hatchlings and recently tarantula spiders (see Fordham et al., 2010a, b). Rangers have also helped botanists, zoologists, ecologists, linguists, anthropologists, and rock art researchers in numerous joint projects in recent years (see, for example, Bowman and Robinson, 2002; Garde, 2004; Telfer and Garde, 2006).

As a senior landowner Namirrkki's status is often revealed in his skill in the appropriate burning-off of country as the dry season advances and there is now a considerable body of research data on the importance of this activity in this region (Haynes, 1985; Bowman et al., 2001; Yibarbuk et al., 2002; RussellSmith et al., 2009). One of co-workers for Bowman, Garde and Saulwick's (2001) research was Big Bill Birriyabirriya, Ivan Namirrkki's elder brother, living at Marrkolidjban. Through detailed interviews conducted in the appropriate language, these authors were able to ascertain the way that burning is used in the hunting of kangaroos through promoting the regrowth upon which the animals feed and also through the highly controlled and communal activity of fire drives. This research also shows the importance, to local landowners, of burning early in the dry season so as not to damage flowering fruit and honey trees and to avoid the development of uncontrollable fires that burn too hot and might kill trees. Recently Garde and others have added to this picture by presenting extensive translated conversations about ecological relationships 
and the use of fire in the rock country region adjacent to Kuninjku lands (Garde et al., 2009). Senior landowners have much to teach younger people employed as rangers in this regard.

Rangers from the Djelk group collaborate with neighbouring ranger groups participating in the West Arnhem Land Fire Abatement Project (Whitehead et al., 2009). As participation in this project shows, Aboriginal habitation of western Arnhem Land and participation in low intensity burning practices involve reduced emissions of greenhouse gases when compared to uncontrolled wildfires in depopulated regions. The fire management activities of the Aboriginal people living in this area are enhanced through the use of region wide satellite tracking and planning of fires as well as aerial incendiary burning of areas of the stone country that are otherwise hard to access. These researchers argue in support of the beneficial environmental effects provided through people living on outstations and making use of these new technologies and for the potential of new income streams from reducing carbon emissions as an innovative model of economic engagement for outstation residents.

The Djelk group and traditional owners in the region have recently negotiated a new Indigenous Protected Area for their country which will see the more permanent establishment of ecological services as contemporary employment on their homelands (Australian Government, 2010). The Djelk Indigenous Protected Area includes over 673,200 hectares of land that has been voluntarily provided for conservation of natural species by the traditional owners. Recognition of an IPA requires management of lands by the owners to internationally agreed standards for sustainable use and habitat protection. The traditional owners can draw upon multiple government and non-government programs, such as Working on Country, that support employment for the management of such lands (see also, Bauman and Smyth, 2007). Rangers are currently being moved from employment under the Community Development Employment Project to these other support programs, although the number of positions that can be supported this way is very small. It must also be acknowledged that this work is highly collaborative between Aboriginal people and balanda and requires the development of sustainable social relations between landowners, government departments, and land management organisations if the work is to be successful (Whitehead et al., 2009: 295-302; see also Hill et al., 2008 for other locations). Certainly the particular religious outlook and skills of Kuninjku provide an advantage in respect to their engagement in such activity (Altman 2003, 2005, 2007a; Burgess et al., 2005).

There are also incipient developments in cultural tourism to visit rock art sites and homeland centres on Kuninjku lands through Bawinanga Aboriginal Corporation Tourism. Kuninjku landowners manage the tour to ensure that the movements of tourists are controlled. Tourists are now seeking to move beyond 
the relatively developed national park areas such as Kakadu, outside of Arnhem Land to the west, and are seeking stronger cultural engagements and direct access to Aboriginal perspectives.

As Altman has revealed, it is the comparatively late impact of colonisation on Kuninjku lands that has given them an advantage in these new enterprise developments. If Kuninjku lands had not been relatively spared from more intrusive forms of development they would not experience the advantages that are now being presented (Altman, 2007a: 4-7; see also, Bauman and Smyth, 2007).

It is important to realise that the engagements with Australian scientists and land managers that this work entails is new activity for Kuninjku. Using GPS to track the spread of introduced animal and plant species, application of poisons, helicopter and quad bike surveys and culls, management of tourists, rock art recording, husbandry of particular species for the aquarium market, and aerial burning and satellite tracking of burn scars in region wide planning and management of carbon emissions are all skills that have been grafted to existing knowledge and management of country and species. Kuninjku ideas regarding the ceremonial management of country are not identical to land management and conservation in the sense that environmental agencies espouse (see also, White and Meehan, 1988: 37-39; Horton, 2000: 127-140; Fordham et al., 2010a). Kuninjku concern for species, people and country is embedded in broader considerations of the maintenance of Ancestrally instituted conventions of behaviour that ensure the preservation of Ancestral spirit and power through time. Indeed it took many years of development training and ongoing support by staff of the Bawinanga Aboriginal Corporation, development of specific formal training programs, as well as engagements with and the Caring for Country Unit of the Northern Land Council to establish understanding of the elements of the position of 'ranger' and to inculcate the regimen of this new kind of work among Kuninjku (Fordham et al., 2010a). The Maningrida School now has a junior ranger program for senior students (Schwab, 2006).

The establishment of the Indigenous Protected Area requires recognition by local people of externally developed standards for maintaining country and species in order to negotiate access to the resources and jobs to conduct these more formalised management activities. It might be expected that managing these different perspectives in the coming years will require considerable negotiation. Nevertheless Kuninjku are now very supportive of the 'two-way' methods involved in the management of their country and there appear to be developing convergences in thinking about country at a deeper level. In these intercultural developments, Kuninjku are learning the scientific framework of western technologies of ecology and conservation and also teaching balanda much about the characteristics of different species and the particular ecological interactions in this unique landscape. These are new kinds of activity and should 
not be simply subsumed as a continuation of pre-existing Kuninjku practice so much as developments that Kuninjku consider appropriate to the way they wish to engage with country, and with balanda, in the present.

It is wrong to identify the religious outlook of people such as Kuninjku as some sort of barrier to be overcome in these developments. Rather, Kuninjku religion provides a base that supports their grasp of more contemporary ecological thinking. As authors such as Latour (1991) and Rose (2005) and Weir (2009) in the Australian Aboriginal context, have pointed out, theories involving hyper-separations of humanity from nature promote a view of nature as a resource and an overconfident attitude in respect to the human technological/ scientific capacity to manage our environment. Such views stem from the Judeo-Christian/Stoic theological root and were exacerbated following the Enlightenment (Bennett, 1983; Latour, 1993; Weir, 2009). Understanding of the ways that ecological destruction is ultimately resulting in damage to humanity requires an appreciation of the complex webs of connectivity of humans in nature. Comprehension of the impacts of ecological destruction involves not just the development of new branches of science focused on ecological complexity and locational particularity but also critical review of fundamental theoretical tenets of western science and theology. In as much as the Kuninjku religious outlook highlights a perspective of connectedness, and their engagement with the natural world requires detailed observation, there is much that they share with the contemporary ecologists with which they work (see, Rose, 2005; Fordham et al., 2010a). In the Maningrida context we might contrast the hubris of the attempt to create a forestry industry in the region in the 1960s with the current investigation of employment in ecologically informed and sustainable conservation activities.

\section{Conclusion}

The chapter opened with a quote from Ivan Namirrkki who was elaborating on his feelings for country. The quote was obtained in a discussion with Namirrkki about why he engages with the world art market (Namirrkki, 2004). The quote involves an assertion that the powers in the earth are not 'invented' but true and necessarily need to be acknowledged by outsiders as well as Kuninjku.

Rather than addressing the topic of ecology as it is more broadly understood, this chapter has focused upon elaborating Kuninjku thinking about country and the continuing powers of djang. This conceptualisation reveals the way that Kuninjku link ideas about human identity to places and to species via an appreciation of their animating Ancestral spirit. Human relationships and political constructions, human responsibility in respect to certain places, 
human interactions with other species, relations between non-human species, considerations of major processes of seasonality and change in the natural world, the aesthetics of art and performance, and emotions and feeling for country are all interlinked on this basis. Similarly new activities enabled as a feature of the changed circumstances of Arnhem Land life are now related into this outlook that has spiritual connectivity at its heart.

There is a growing self-consciousness among Kuninjku of the need to make balanda understand these things and of the threats posed by those who do not. Indeed many of the enterprise engagements of Kuninjku such as the art market or environmental services involve communication with balanda about the value of the Ancestral world for political as well as economic reasons. Although Kuninjku are willing partners in the two way exchanges that characterise their new circumstance this does not mean that they necessarily accept the broader range of balanda values. Through their engagements in these new activities Kuninjku also readily express their differences from balanda.

The homelands movement was not the dream of left wing policy ideologues to preserve a passing world so much as an accommodation by balanda of Aboriginal agency in creating new forms of social development where country, understood as a spiritual unity of people with the life of a place, was a central concern. This new form of settlement involved an explicit rejection of attempts at assimilation in the 1960s and economic development as practiced at Maningrida at that time. Kuninjku voted with their feet in the early 1970s by moving back to country even though support was very limited in the early years. Rowse (1998) too has shown how the under-appreciation of Aboriginal attachments to country frustrated work force proposals and assimilationist policies in central Australia during this period. Folds (2001) reveals in detail the means by which the Pintupi from central areas of the Northern Territory maintained their concern to preserve local cultural values and undermined and transformed successive mainstream programs aimed at assimilation. Aboriginal people have the relative power to effect these transformations in remote situations and to confound policies and programs issued by central bureaucracies and governments. The more successful alternative involves respect for the creative way that Aboriginal people are melding distinct knowledge and value frameworks in these locales and the development of programs that seek Aboriginal engagement on these terms.

Kuninjku have already identified appropriate forms of development in their country that assert core cultural values in new activities. Mainstream or coercive development proscriptions that ignore Kuninjku belief and attempt to divorce Kuninjku from their country, and impose conceptions of 'real' work, 'real' education, or 'real' health options will fail in the same way as earlier attempts at assimilation because they cannot engender Aboriginal engagement. 
Considerations of development must come to grips with the fundamental epistemological challenge of Kuninjku belief of Ancestral creation - a belief from which all other conceptions of reality flow.

\section{References}

Altman, J 1984, 'The dietary utilisation of flora and fauna by contemporary hunter-gatherers at Momega outstation, north-central Arnhem Land', Australian Aboriginal Studies 1984(1): 35-46.

- 1987, Hunter Gatherers Today: An Aboriginal Economy in North Australia, Australian Institute of Aboriginal Studies, Canberra.

- 2003, 'People on country, healthy landscapes and sustainable economic futures: the Arnhem Land case', The Drawing Board: An Australian Review of Public Affairs 4(2): 65-82.

- 2004, 'Brokering Kuninjku art: artists, institutions and the market', in Crossing Country; The Alchemy of Western Arnhem Land Art, H Perkins (ed), Art Gallery of New South Wales, Sydney: 173-187.

- 2005, 'Development options on Aboriginal land: sustainable Indigenous hybrid economies in the twenty-first century', in The Power of Knowledge: The Resonance of Tradition, L Taylor, GK Ward, G Henderson, R Davis and LA Wallis (eds), Aboriginal Studies Press, Canberra: 34-48.

- 2007a, 'Alleviating poverty in remote Australia: the role of the hybrid economy', CAEPR Topical Issue No. 10/2007, Centre for Aboriginal Economic Policy Research (CAEPR), The Australian National University (ANU), Canberra.

- 2007b, 'In the name of the market?', in Coercive Reconciliation: Stabilise, Normalise, Exit Aboriginal Australia, J Altman and M Hinkson (eds), Arena Publications Association, North Carlton, Victoria: 307-321.

— and M Hinkson 2007a, 'Mobility and modernity in Arnhem Land: the social use of Kuninjku trucks', Journal of Material Culture 12(2): 181-203.

- and M Hinkson (eds) 2007b, Coercive Reconciliation: Stabilise, Normalise, Exit Aboriginal Australia, Arena Publications Association, North Carlton, Victoria.

Bauman, T and D Smyth 2007, Indigenous Partnerships in Protected Area Management: Three Case Studies, Australian Institute of Aboriginal and Torres Strait Islander Studies, Canberra. 
Bennett, DH 1983, 'Some aspects of Aboriginal and non-Aboriginal notions of responsibility to non-human animals', Australian Aboriginal Studies 1983(2): 19-24.

Bowman, DMJS, M Garde and A Saulwick 2001, 'Kunj-ken makka man-wurrk: fire is for kangaroos: interpreting Aboriginal accounts of landscape burning in central Arnhem Land', in Histories of Old Ages: Essays in Honour of Rhys Jones, A Anderson, I Lilley and S O'Connor (eds), Pandanus Books, Canberra: 61-78.

Bowman, DMJS and CJ Robinson 2002, 'The getting of nganabbarru: observations and reflections on Aboriginal buffalo hunting in northern Australia', Australian Geographer 33(2): 191-206.

Burgess, CP, FH Johnston, DMJS Bowman and PJ Whitehead 2005, 'Healthy country: healthy people? Exploring the health benefits of Indigenous natural resource management', Australian and New Zealand Journal of Public Health 29(2): 117-122.

Cooke, Peter 1981, 'An exhibition of paintings by Djakku (Peter Marralwanga)', Maningrida Arts and Crafts, Maningrida.

Deger, J 2006, Shimmering Screens: Making Media in an Aboriginal Community, University of Minnesota Press, Minneapolis, Minnesota.

Department of Environment, Water, Heritage and the Arts (DEWHA) 2010, Djelk Arnhem Coast, Northern Territory, Department of Environment, Water, Heritage and the Arts, Canberra, available at: <http://www. environment.g.au/indigenous/ipa/declared/djelk.html>

DEWHA - see Department of Environment, Water, Heritage and the Arts

Evans, N 2003, Bininj gun-wok: A Pan-dialectical Grammar of Mayali, Kunwinjku and Kune, Pacific Linguistics, The Australian National University, Canberra.

Folds, R 2001, Crossed Purposes: The Pintupi and Australia's Indigenous Policy, University of New South Wales Press, Sydney.

Fordham, A, W Fogarty, B Corey and D Fordham 2010a, Knowledge Foundations for the Development of Sustainable Wildlife Enterprises in Remote Indigenous Communities of Australia, Centre for Aboriginal Economic Policy Research, ANU, Canberra.

- 2010b, The Viability of Wildlife Enterprises in Remote Indigenous Communities of Australia: A Case Study, Centre for Aboriginal Economic Policy Research, ANU, Canberra. 
Garde, M 2004, 'Growing up in a painted landscape', in Crossing Country; The Alchemy of Western Arnhem Land Art, H Perkins (ed), Art Gallery of New South Wales, Sydney: 107-111.

- in collaboration with Bardayal Lofty Nadjamerrek, Mary Kolkkiwarra, Jimmy Kalarriya, Jack Djandjomerr, Bill Birriyabirriya, Ruby Bilindja, Mick Kubarkku and Peter Biless 2009, 'The language of fire: seasonality, resources and landscape burning of the Arnhem Land plateau', in Culture, Ecology and Economy of Fire Management in North Australian Savannas Rekindling the Wurrk Tradition, J Russell-Smith, PJ Whitehead and P Cooke (eds), CSIRO Publishing, Collingwood, Victoria: 85-164.

Haynes, CD 1978, 'Land, trees and man (gunret, gundulk, dja bining)', Commonwealth Forestry Review 57(2): 99-106.

- 1985, 'The pattern and ecology of munwag: traditional Aboriginal fire regimes in north-central Arnhemland', Proceedings of the Ecological Society of Australia 13: 203-214.

Hiatt, L 1965, Kinship and Conflict: A Study of an Aboriginal Community in Northern Arnhem Land, The Australian National University, Canberra.

Hill, R, EK Harding, D Edwards, J O'Dempsey, D Hill, A Martin and S McIntyreTamwoy 2008, A Cultural and Conservation Economy for Northern Australia, Land and Water Australia, Canberra.

Hinkson, M and B Smith 2005, 'Introduction: conceptual moves towards an intercultural analysis', Oceania 75(3): 157-167.

Horton, D, 2000, The Pure State of Nature: Sacred Cows, Destructive Myths and the Environment, Allen \& Unwin, St Leonards, New South Wales.

Hughes, H 2007, Lands of Shame: Aboriginal and Torres Strait Islander 'Homelands' in Transition, Centre for Independent Studies Ltd, St Leonards, New South Wales.

Keen, I 1994, Knowledge and Secrecy in an Aboriginal Religion, Clarendon Press, Oxford.

Kettle, E 1967, Gone Bush, The Devonshire Press, Sydney.

Kyle-Little, S 1957, Whispering Wind: Adventures in Arnhem Land, Hutchinson \& Co, London.

Latour, B 1993, We Have Never Been Modern, Harvard University Press, Cambridge, Mass. 
McDonald, H 2003, 'The fats of life', Australian Aboriginal Studies 2003(2): 53-61.

Merlan, F 1998, Caging the Rainbow: Places, Politics, and Aborigines in a North Australian Town, University of Hawai'i Press, Honolulu.

- 2005, 'Explorations towards intercultural accounts of socio-cultural reproduction and change', Oceania 75(3): 167-183.

Morphy, H 2008, “'Joyous maggots”: the symbolism of Yolngu mortuary rituals', in An Appreciation of Difference: WEH Stanner and Aboriginal Australia, M Hinkson and J Beckett (eds), Aboriginal Studies Press, Canberra: 137-150.

Namirrki, I 2004, 'Our spirits lie in the water', in Crossing Country; The Alchemy of Western Arnhem Land Art, H Perkins (ed), Art Gallery of New South Wales, Sydney: 112-113.

Northern Territory Government 2009, ‘Working future: Outstations/homelands policy', Department of Chief Minister, Northern Territory Government, Darwin, available at: <http://www.workingfuture.nt.gov.au/download/ Headline_Policy_Statement.pdf $>$

Parliament of the Commonwealth of Australia 1987, Return to Country: The Aboriginal Homelands Movement in Australia, House of Representatives Standing Committee on Aboriginal Affairs, Canberra.

Perkins, H (ed) 2004, Crossing Country; The Alchemy of Western Arnhem Land Art, Art Gallery of New South Wales, Sydney.

Povinelli, EA 1993, Labor's Lot: The Power, History, and Culture of Aboriginal Action, The University of Chicago Press, Chicago.

Rose, D 2005, 'An Indigenous philosophical ecology: situating the human', Australian Journal of Anthropology 16(3): 294-305.

Rowse, T 1998, White Flour, White Power: From Rations to Citizenship in Central Australia, Cambridge University Press, Cambridge.

Russell-Smith, J, PJ Whitehead and P Cooke (eds) 2009, Culture, Ecology and Economy of Fire Management in North Australian Savannas Rekindling the Wurrk Tradition, CSIRO Publishing, Collingwood, Victoria.

Schwab, RG 2006, Kids, Skidoos and Caribou: The Junior Canadian Ranger Program as a Model for Re-engaging Indigenous Australian Youth in Remote Areas, Centre for Aboriginal Economic Policy Research, ANU, Canberra. 
Country, Native Title and Ecology

Tamisari, F 2005, 'The responsibility of performance; the interweaving of politics and aesthetics in intercultural contexts', Visual Anthropology Review 21(1\&2): 47-62.

Tatz, CM 1964, 'Aboriginal administration in the Northern Territory of Australia', unpublished PhD thesis, Australian National University, Canberra.

Taylor, L 1990, 'The rainbow serpent as visual metaphor in western Arnhem Land', Oceania 60: 329-344.

— 1996, Seeing the Inside: Bark Painting in Western Arnhem Land, Clarendon Press, Oxford.

— 2008, "They may say tourist, may say truly painting": aesthetic evaluation and meaning of bark paintings in western Arnhem Land, northern Australia', Journal of the Royal Anthropological Institute (NS) 14: 865-885.

Telfer, WR and MJ Garde 2006, 'Indigenous knowledge of rock kangaroo ecology in western Arnhem Land, Australia', Human Ecology 34(3): 379-406.

Vanstone, A 2005, 'Beyond conspicuous compassion: Indigenous Australians deserve more than good intentions', Address to the Australia and New Zealand School of Government, Australian National University, Canberra, 7 December 2005, available at: < http://parlinfo.aph.gov.au/parlInfo/download/ media/pressrel/GH9I6/upload_binary/gh9i63.pdf>

Weir, JK 2009, Murray River Country: An Ecological Dialogue with Traditional Owners, Aboriginal Studies Press, Canberra.

White, N and B Meehan 1988, 'Traditional ecological knowledge: a lens through time', in Traditional Ecological Knowledge: Wisdom for Sustainable Development, NM Williams and G Baines (eds), Centre for Resource and Environmental Studies, Australian National University, Canberra: 31-40.

Whitehead, PJ, P Purdon, PM Cooke, J Russell-Smith and S Sutton 2009, 'The West Arnhem Land Fire Abatement (WALFA) project: the institutional environment and its implications', in Culture, Ecology and Economy of Fire Management in North Australian Savannas Rekindling the Wurrk Tradition, J Russell-Smith, PJ Whitehead and P Cooke (eds), CSIRO Publishing, Collingwood, Victoria: 287-312.

Yibarbuk, D, PJ Whitehead, J Russell-Smith, D Jackson, C Godjuwa, A Fisher, P Cooke, D Choquenot, DMJS Bowman 2002, 'Fire ecology and Aboriginal land management in central Arnhem Land, northern Australia: a tradition of ecosystem management', Journal of Biogeography 28(3): 325-343. 


\section{Archival sources}

Evans, EC 1963, 'Patrol to establish a road link between Oenpelli and Maningrida', Typescript, Department of Aboriginal Affairs, National Archives of Australia, File 66/3790.

Sweeney, G 1939, Report of patrol in the Junction Bay, Liverpool River and Tomkinson River areas, July-August 1939, National Archives of Australia, File 64/2231.

\section{Legislation}

Aboriginal Lands Rights Act Northern Territory 1976 (Cth) 